\title{
Mentoring Mentors in Cooperative Software Engineering Education Programmes
}

\author{
Joseph Maguire \\ University of Glasgow \\ Glasgow, United Kingdom \\ joseph.maguire@glasgow.ac.uk \\ Steve Draper \\ University of Glasgow \\ Glasgow, United Kingdom \\ steve.draper@glasgow.ac.uk
}

\author{
Nathalie Sheridan \\ University of Glasgow \\ Glasgow, United Kingdom \\ nathalie.sheridan@glasgow.ac.uk \\ Quintin Cutts \\ University of Glasgow \\ Glasgow, United Kingdom \\ quintin.cutts@glasgow.ac.uk
}

\begin{abstract}
Cooperative programmes are principally partnerships between academia and industry to deliver education partly on campus and partly in the workplace. Mentors in the workplace are crucial in such cooperative programmes as they scaffold appropriate development activities for students. A workplace mentor in this situation is important not only for the development of detailed technical knowledge, but also in the development of software engineering skills that are almost never in fact taught in higher education, e.g. navigating large, neglected code bases. Consequently, workplace mentors are a key component of any high-quality education programme delivered in partnership with industry. However, higher education institutions and enterprises not only need to appreciate the importance of mentors in such schemes, but also ensure such staff are supported to use their experience to increase their skill as a mentor. Mentors need the space and support to reflect on their own practice, develop skills and attain new knowledge. In this sense, the challenge is not dissimilar to that faced by computing science school teachers that need to continually consider their own practice as well as have the time to consider emerging programming languages and frameworks. Many of the structures and existing research on how to support computing science school teachers could be adapted to support these workplace mentors, e.g. support groups.

In this poster, we present initial research and models for mentoring mentors in cooperative software engineering programmes. The aim is to share initial work, receive feedback and to connect with potential collaborators.
\end{abstract}

\section{CCS CONCEPTS}

- Social and professional topics $\rightarrow$ Computing education.

\section{KEYWORDS}

work-based learning; software engineering education; mentors

Permission to make digital or hard copies of part or all of this work for personal or classroom use is granted without fee provided that copies are not made or distributed for profit or commercial advantage and that copies bear this notice and the full citation on the first page. Copyrights for third-party components of this work must be honored

For all other uses, contact the owner/author(s).

ICER '19, August 12-14, 2019, Toronto, ON, Canada

(C) 2019 Copyright held by the owner/author(s).

ACM ISBN 978-1-4503-6185-9/19/08.

https://doi.org/10.1145/3291279.3341205

\section{ACM Reference Format:}

Joseph Maguire, Nathalie Sheridan, Steve Draper, and Quintin Cutts. 2019. Mentoring Mentors in Cooperative Software Engineering Education Programmes. In International Computing Education Research Conference (ICER '19), August 12-14, 2019, Toronto, ON, Canada. ACM, New York, NY, USA, 1 page. https://doi.org/10.1145/3291279.3341205

\section{INTRODUCTION}

Cooperative higher education programmes involve the interplay of academics, students and workplace mentors. Mentors support students in the workplace, but also have their own significant responsibilities. Consequently, mentors also require help and support.

\section{LEARNING LESSONS FROM COMPUTING SCIENCE SCHOOL TEACHERS}

The challenge for workplace mentors is not dissimilar to computing science teachers. Initial research suggests effective models are:

- Professional Learning Networks. The Professional Learning And Networking for Computing (PLAN C) programme is example to develop computing science teachers in Scotland through development of self-staring hubs [1].

- Disciplinary Commons. The model expects educators to organise regular meetings to critique and consider their practices and different environments [3].

- Peer coaching. Educators can work in pairs to support and develop their own capability [2].

The aforementioned models can act as bases to support mentors, but here they must accommodate the restrictions of industry. Consequently, in the poster we propose some possible adaptations.

\section{REFERENCES}

[1] Quintin Cutts, Judy Robertson, Peter Donaldson, and Laurie O’Donnell. 2017. An evaluation of a professional learning network for computer science teachers. Computer Science Education 27, 1 (2017), 30-53.

[2] Sue Sentance, Mark Dorling, and Adam McNicol. 2013. Computer science in secondary schools in the UK: Ways to empower teachers. In International Conference on Informatics in Schools: Situation, Evolution, and Perspectives. Springer, 15-30.

[3] Josh Tenenberg and Sally Fincher. 2007. Opening the door of the computer science classroom: the disciplinary commons. ACM SIGCSE Bulletin 39, 1 (2007), 514-518. 